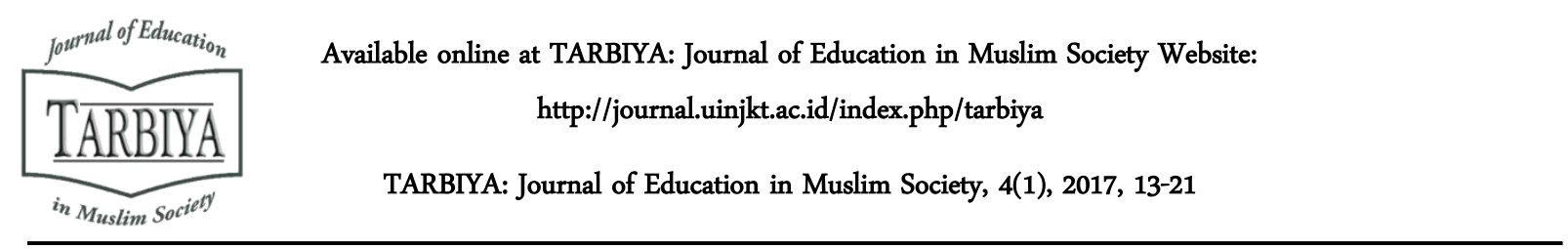

\title{
AN INVESTIGATION OF TEACHER-STUDENT RELATIONSHIP IN ISLAMIC HISTORY OF EDUCATION
}

\author{
Muhammad Zulqarnain \\ National University of Modern Languages (NUML), Islamabad, Pakistan \\ E-mail: zulqarnain4386@gmail.com
}

Received: $18^{\text {th }}$ March 2017; Revised: $15^{\text {th }}$ April 2017; Accepted: $18^{\text {th }}$ June 2017

\begin{abstract}
This paper is an attempt to explore the nature of relationship between teachers and students in Islamic history of education. The research was triggered of the result of investigation that highlighted disappointing teacher-student relationship in contemporary education system. By employing descriptive and qualitative research method the study established that teacher-student relationship had been given an astonishing milieu in Islamic history and was considered one of the core causes for education par excellence. This relationship was based on care, sympathy, mutual understanding, cooperation and common respect. It was concluded that this healthy relationship enhanced class participation, confidence, critical thinking, research and oral communication skills including in areas of interpersonal skills and personality development of students. The research, therefore, recommends establishing healthy relationship among students and teachers by captivating direction from Islamic history of education since it is perceived not only to improve quality of education but also to equip learners with additional competencies.
\end{abstract}

Keywords: relationship; teacher-student; Islamic history; Islamic education; contemporary education

\section{Abstrak}

Artikel ini adalah sebuah percobaan untuk meneliti hakikat hubungan antara guru dan siswa dalam sejarah pendidikan Islam. Penelitian dipicu sebagai hasil dari investigasi yang mengarisbawahi hubungan buruk antara guru dan siswa dalam sistem pendidikan yang kontemporer. Dengan menggunakan metode penelitian deskriptif dan qualitatif, studi membentuk bahwa hubungan guru-siswa sudah diberikan lingkungan pergaulan yang mengherankan dalam sejarah Islam dan dianggap salah satu akar penyebab persamaan mutu pendidikan. Hubungan ini terbangun atas dasar perhatian, simpati, saling memahami, kerjasama dan menghormati. Hal tersebut disimpulkan bahwa hubungan yang sehat ini meningkatkan partisipasi kelas, kepercayadirian, berpikir kritis, penelitian dan kemampuan komunikasi secara lisan termasuk dalam ranah kemampuan interpersonal dan pengembangan diri siswa. Oleh karena itu, penelitian ini merekomendasikan untuk membangun hubungan yang sehat antara siswa dan guru dengan mengarahkan arahan dari sejarah pendidikan Islam karena dianggap tidak hanya untuk meningkatkan kualitas pendidikan, tetapi juga untuk membekali siswa dengan kompetensi tambahan.

Kata kunci: Hubungan, guru-siswa; sejarah Islam; pendidikan Islam; pendidikan kontemporer

How to Cite : Zulqarnain, M. (2017). An Investigation of Teacher-Student Relationship in Islamic History of Education. TARBIYA: Journal of Education in Muslim Society, 4(1), 13-21. doi:10.15408/tjems.v4i1. 5317.

Permalink/DOI: http://dx.doi.org/10.15408/tjems.v4i1.5317 


\section{Introduction}

In oxford dictionary, the term 'relationship' refers to "the way in which two or more people or things are connected, or the state of being connected." In an educational context, 'relationship' expresses the connection of communication, behavior, and understanding between teacher and student.

Educationists believe that teacher-student relationship is the most influential element within the learning process as "It has immense effects on students' learning, schooling experience (Liberante, 2012) as well as the behavioral adjustment” (Urooj, 2013). According to (Ulwan, 2000), psychologists, sociologists, and educationists are agreed upon the forming of the close relationship between teacher and student to develop the scientific, moral and psychological aspect of education. Therefore an appropriate relationship plays the cardinal role in the students' learning. An effective relationship, on the one hand, facilitates the teacher in teaching process while on the other hand, grooms the students to develop their interest in studies.

Unfortunately, the relationship between teachers and students has been found inadequate in present-day education. The researcher in his M. Phil research surveyed to explore the degree of relationship between teachers and students and concluded that the relationship among them was unsatisfactory (Zulqarnain, 2014). This unhealthy relationship prompted the researcher to explore the teacher-student relationship in Islamic history of education. Secondly, it is a fact that strong and positive relationship promotes quality of education and equips the learners with additional skills. It was therefore hypothesized by the researcher that one of the secrets of Muslims' ideal education system was a healthy teacherstudent relationship which played an important role in producing such great men of knowledge who left an immense influence in the history of knowledge over the centuries. Therefore this study is designed to find out the teacher-student relationship at in Islamic history of education. Exploring teacher-student relationship in Islamic history would provide an opportunity to critically examine and improve the relationship in contemporary education system.

Overall, this study intended to investigate the teacher-student relationship in the golden age of Muslims' education. However, the study intended to accomplish the following particular objectives: (1) to discover the nature of relationship in Islamic history of education and its impact on teaching learning outcome; and (2), to examine the relationship in contemporary education in context of Islamic history of education and (3), to establish the perception that strong and positive relationship was the secret of Muslims best education which on hand enhanced (a) class participation, (b) confidence, (c) critical thinking,(d) creativity, (e) personality development, and (f) oral communication skills of the students while on the other hand provided an opportunity to the teachers to accomplish the educational goals.

Muslim educationists laid a great emphasize to form a strong positive relationship between teacher and student. Some wrote specific books on nature of relationship while others made particular chapters in their books. Tazkirat-ulSamey-wal-Mutakallim by Ibn-e-Jamayah, Talim-ul-Muta'allimTariq al-Ta-Allum by Burhan-ul-Islam al-Zarnuji, are famous books written on the manners of teacher and student regarding acquiring knowledge. Likewise Imam Ghazali in his famous book Ihya-ul-Uloom wrote the manners of knowledge for both; teacher and student.

In Muslim education system, every teacher and student were acquainted with one another at an intimate level (Moes, n.d). The relationship 
between teacher and student in Islamic education, even at primary level has been found better than the today's relationship at post graduate level in Europe. The reason was that education was not merely to deliver knowledge but also to develop all necessary skills for the students, and it was impossible without establishing a personal relationship between teacher and students (Murad, 1985). This marvelous relationship developed intellectual, physical, moral, spiritual and materialistic capabilities of the students which led them towards outstanding educational progress.

\section{Method}

This exploratory study was designed to discover the teacher-student relationship in Muslims history of education. The descriptive and qualitative method was used for the collection and analysis of data collection. A vast amount of previously published and parallel literature including research articles, periodicals, theses, research reports and books of Islamic history of education was thoroughly reviewed. Secondary sources including Internet, library, and magazines, etc. were also pulled in after careful assurance of their validity and reliability. Ph.D. scholars, professors of history and Islamic education, were consulted whose guidance, and opinions added significant value to the recommendations and endorsed the findings of paper.

\section{Findings and Discussion}

\section{Teachers' Relationship with Students}

Forming strong and the positive teacherstudent relationship has been distinguished quality in Muslim education throughout the history. Every teacher was supposed to establish a personal relationship with his students. For instance: In the time of second Caliph of Islam
(Hazrat Umar R.A), four thousand students were studying under the supervision of Hazrat Muaz bin Jabal (R.A) and he established personal relationship with every single student (Murad, 1985).

Tashka Prasad has drawn a sketch of teacher's relationship with the students in Islamic history that teacher had the pure intention, treated students like his own children; condemned vices and unseemly behavior, always began with most important and encouraged continuously for advanced learning. His words were matching with his actions, not too much joking, not getting angry, encouraging for asking questions and avoiding the egotistic disputation. He did not stuck advanced students with easy stuff, planned his lessons advanced, behaved equally with students and used to get ready to fulfill all needs of students (Moes, n.d). Following points provide a brief sketch of teachers' relationship with their students.

\section{a. Understanding of Students' Psychology}

Students differ from one another in capabilities, talent, and level of understanding. Thus the best teacher always teaches his students by keeping in view their aptitudes and level of competence. (Mustafai, 2010) Emphasizes on the psychological understanding of students that an educational system should be designed by the capabilities, needs, interests, hobbies, and emotions of the students. In Islamic education system "A teacher was instructed to examine the abilities of student in order to behave with him accordingly" (Shalbi, 1999). It was essential for a teacher to be acquainted with the caliber and absorbing level of the students. Overburdening and pushing the pupils beyond their capacity was absolutely condemned by Muslim educationists. In this connection, Al-Ghazali stated the fruits of proper and harms of improper feeding that "to feed someone with the right food is to give life; to burden someone with what is not right can 
only cause ruin". Therefore teacher must avoid bringing them to a level of knowledge that they cannot absorb (Nofal, 2000). Ibn-e-Jamayah wrote that the teacher is expected to impart his student such explanation of the text which is according to his intellect (Kanani, 2004)..

\section{b. Counseling and Guidance}

Muslim teacher was very careful about his students and used to guide them in both: curricular and co-curricular activities. Bu Ali Sina stated that it was the responsibility of teacher to examine the capabilities of student and suggest him suitable subjects. Asfahani emphasized the same point that a teacher should choose the intelligent students for his discipline with such care as one chooses the person for the marriage of his daughter (Shalbi, 1999). Some examples could be seen that once a student chose a discipline and teacher guided him towards another and later he became a prominent scholar of that particular discipline. For instance, Imam Bukhari, a renowned scholar of hadith, first attended the classes of Muhammad bin AlHassan but was guided later by his teacher to join the discipline of Hadith sciences. He, on his teacher's advice, changed his discipline and became a distinguished scholar of hadith (Shalbi, 1999)

\section{c. Attitude towards students}

Muslim teachers equally behaved with their students irrespective of their richness and poorness. It was an amazing fact that most of the renowned scholars in Islamic history belonged to poor financial background. (Shalbi, 1999) has quoted some scholars who were very poor but the affectionate behavior of teachers polished their talent and enabled them to make a marvelous contribution to the history of knowledge. For instance, Abu Tamam Al Tai belonged to a poor family, but the adequate behavior of teachers made him a famous poet. Imam Shafi was an orphan and his mother was even unable to provide him pen and paper. His teacher (Imam Malik) paid him special attention and he became third great jurist of Islam. A great Muslim philosopher and sufi Al-Ghazali was very poor but caring behavior of his teacher AlJuvini made him such a great scholar that he earned the title of "Hujjat-ul-Islam" (Proof of Islam). It was often observed that the teachers by themselves helped their students so that they could continue their education without any interruption. Imam Abu Yousuf belonged to extremely poor family due to which he did not attend the lectures regularly. When his teacher (Imam Abu Hanifa) came to know, he took his financial responsibility on his own shoulders and continued to support till the completion of his education. Later Abu Yousuf became one of the great pillars of Hanafi school of thought (Shalbi, 1999).

The lenient behavior of teacher encourages the student to take interest into studies (Sheikh, 1984). Muslim teacher was a model of sympathy who always behaved politely with the students. The principle behind this was the obedience of Holy Prophet as he instructed the teachers to do so. For example, Hazrat Abu Saeed Khudri used to say 'welcome' to the seekers of knowledge. He said that we are advised by Holy Prophet to teach and treat you with respect (Ibn-e-Qattaan, 1997).

\section{d. Appreciation and Reward}

Appreciation helps students to build up the level of confidence and to achieve excellence in education. It is established by the educationists that the students who are continuously pursued, compete their classmates and produce better results. Muslim teachers used to encourage and appreciate outstanding students on excellent achievements. Ibn-e-Jamayah wrote about the methodology of encouraging students that a teacher should encourage his students by reciting verses of Holy Quran, traditions of Prophet 
Muhammad (PBUH), telling different events and couplets showing the excellence of scholars and that the scholars are inheritors of prophets (Kanani, 2004). According to Al Ghazali, the student who is obedient to his teacher, having good morals and shows an excellent performance in academia, should be "honored and praised in public to be encouraged and to incite others to imitate him" (Nofal, 2000). Different methods were used to appreciate the students in Islamic education. Sometimes, students had to ride on the camels, and the people throw almonds and walnut on them, while sometimes they were awarded scholarships and cash prizes (Shalbi, 1999)

\section{e. The Concept of Punishment}

Muslim educationists had different opinions regarding punishment. However, the concept of unnecessary beating has been rejected by all of them. A conditional and minor punishment was allowed as an utmost step, subjected to the failure of all remedial measures. The purpose of punishment was to make the students disciplined and develop good morals.

Ibn-e-Khaldun did not agree even with the conditional and minor punishment. He was of the view that punishment produces negative effects and prompts a student to become rebel from the studies. According to him, the punishment stops student's learning, personality development, (Nadvi, 1995), develops habit of lying and deceiving others. These bad habits increase day by day and ultimately ruin the life of child (Shalbi, 1999). According to Al-Ghazali, a teacher should avoid the punishment to his level of best. If a student commits mistake, teacher should ignore it first. If he commits the same mistake again, the teacher should call him separately and advise him not to do so. In case of failure of counseling, he can slightly punish the student (Nofal, 2000). Sheikh Ibn-ul-Ikhva wrote about the manners of punishment that a student should not be punished with such stick which could facture the bone and not with that, which may not effect. Moreover, a teacher should beat such parts of the body where there is no possibility of breakage (Fazl-e-Ilahi, n.d). Mufti Taqi Usmani refers the methodology of Ashraf Ali Thanvi in case of punishment. He was of the view that parents should not punish the child soon after the commitment of mistake because at that time they would exceed the limits because of anger. So when the situation went away, they could punish the child by showing an artificial anger. In this way they will not exceed the limits and purpose of punishment will also be fulfilled (Usmani, 2010).

\section{Students' Relationship with Teachers}

It was the distinguished quality of Islamic education system that Muslim students formed strong personal and spiritual relationship with their teachers and considered it an act of virtue. They believed that the failure of such type of relationship would lead towards unprofitable knowledge. Therefore they developed a strong positive relationship based on care, obedience, trust, and respect. In Sufism, the relationship between Sheikh (Master) and his Murid (pupil) could be seen amazing as it seems sometimes stronger than that of relationship of a man with Allah Almighty. The reason was that the Murid thought that the failure of such nature of relationship with his Sheikh would cause the failure of a student towards Allah Almighty (Alkanderi, 2001).

Following few points reflect students' behavior with the teachers in Islamic history of education.

\section{a. Etiquettes of Learning}

Muslim scholars laid a great emphasize on etiquettes of acquiring knowledge. According to Hazrat Abu Amr bin ula, there are five steps of acquiring knowledge: The first step is to be 
silent, second is listening with concentration, third is good questioning, fourth is memorizing by heart and fifth is preaching to the person capable of" (Qasim, 2011).An ideal example could be seen in the time of Holy Prophet PBUH that when he used to teach the companions, they were accustomed to listening with such concentration if the birds were sitting on their heads and they will fly away by minor movement. (Asif, 2004) stated that When Hazrat Imam Malik used to teach the traditions of Holy Prophet PBUH, the students looked like statues and only the voice of their breaths could be heard. (Undlasi, 1977) Quoted the advice of Hazrat Husain to his son: O my son! Try to learn instead of talking in the company of scholars. He further said that just like the etiquettes of silence, etiquettes of listening should also be acquired.

\section{b. Trust in Teachers}

Muslim students trusted their teachers and believed that they ever thought for their better future. (Naqshbandi, 2009) Quoted a simile that a student should be in front of his teacher just like a patient in front of doctor. He must consult all of his affairs, problems, and issues with the teacher. Some examples could be seen in Islamic history which reflects the students' trust upon their teachers. It was often observed that a teacher advised a student to change his discipline and he left his personal opinion by trusting his teacher. After some time he saw the consequences of his trust and became an authority in that discipline (Shalbi, 1999).

\section{c. Attitude towards Teachers}

Teacher in Islamic education was not merely responsible for inculcating knowledge but was equally responsible for guiding students in all affairs. This care of teacher demanded the pupil, in response, that he should respect the teacher, give him high status and behave with him like his father (Nofal, 2000). Hazrat Ali
(R.A) explained the etiquettes of behaving with the teacher that whenever you meet with a scholar first greet him separately than others, sit in front of him obediently, don't imply with hands, don't blink the eyes, don't argue with him and don't tease him by asking(un-necessary) questions (Undlasi, 1977). Moreover a scholar should not be asked much questions, should not be embarrassed on answer, not be pursued if he is tired, not be searched his secrets and faults, his excuse should be accepted in case of mistake and the nation should fulfill his needs until he protects the religion of Allah Almighty (Ghazali, n.d).The Holy Prophet (PBUH) is reported to have said: "Scholars are inheritors of Prophets" (Dawd, 2009). Some scholars argued with this hadith that to talk with Holy Prophet (PBUH) in a loud voice was prohibited likewise one should not talk with a scholar in a loud voice. (Naqshbandi, 2009) Says that a teacher should not be called saying 'you' but be called by saying 'O my leader O my leader.' Muslim educationists also emphasized to behave adequately with the relatives of teachers. (Naqshbandi, 2009) writes that it was necessary for a student to treat with the relatives of a teacher with the manners of love and respect.

\section{d. Obedience and Humbleness}

Obedience and humbleness were considered primary qualities of a student in Islamic education. Nonobedient and egoistic attitude had been condemned by Muslim Scholars. It was established by Muslim scholars that acquiring knowledge is not possible without obedience and humbleness therefore Muslim educationist stressed upon the students to be obedient and humble. According to Al-Ghazali, student must obey the instructions of teacher solemnly (Naqshbandi, 2009). He further said that knowledge is the enemy of arrogance. Therefore, a student should be a model of humbleness and must avoid from even little kind of arrogance. According to him, a student should regard his 
teacher's opinion up to utmost level, and anyone who gives priority to his opinion against the teacher loses. The student has no right to argue in front of the teacher as it is harmful to him. He explains this phenomenon by quoting the example of Hazrat Musa and Hazrat Khidr that Hazrat Musa could not show patience on the actions of Hazrat Khidr which ultimately separated their ways.

\section{e. Respect}

One of the distinguished qualities of Muslim student was his respectful behavior towards teachers. Imam Ghazali was of the view that a student should respect his teacher more than his parents. He argued that parents caused him to bring in this mortal world while the teachers made him immortal through education (Shalbi, 1999). (Naqshbandi, 2009) States that Hazrat Ali said I am the slave of a person who taught me even a single word if he wanted to sale me he could, if he wanted to free me, and if he wanted to make me slave he could do so. Hazrat Shobah used to say that the person from whom I heard a single hadith I am his slave (Undlasi, 1977). Sheikh Sadi said if anyone wants his son to be a religious scholar, should respect the scholars. If his son would not become a scholar, his grandson will become scholar (Naqshbandi, 2009). The phenomena behind this was the belief that Student will not get fruits of knowledge and without respecting teacher (Naqshbandi, 2009). Therefore students showed utmost respect towards their teachers and sometimes adopted the teacher's name as part of their name (Bhatti, 2010).

The Holy Prophet (PUBH) advised his followers to respect and behave with the scholars politely. He was reported to have said that respecting an elder Muslim, religious scholar, hafiz e Quran, righteous king, and teacher is just like respecting the Allah Almighty (Naqshbandi, 2009). He gave high position to a teacher by saying that there are three fathers of you: one who brought you from extinction to being, second who gave you his daughter, third who gave you knowledge (Bhatti, 2010). By the traditions of Holy Prophet (PUBH), Muslim scholars established such unique examples of respecting teachers which had never been seen in the history. For instance, Imam Shafi, a great jurist of Islam, used to turn the pages of paper slowly that the teacher could not listen its voice (and get disturbed) (Naqshbandi, 2009).Once Imam Ahmad bin Hanbal leaned during discussion, by hearing the name of his teacher sat straight and said it would be bad that the name of elders (scholars) come and we sit by underpinning (Naqshbandi, 2009). Furthermore he, due to the behavior of respect, did not take the name of his teacher and used to tell about him with surname. Once Hazrat Zaid bin Sabit offered a funeral prayer then Hazrat Ibn-e-Abbas came to him and held the paddle of his horse. Hazrat Zaid said "O, brother of Holy Prophet leave it" (as you are more respectful person) in return; he replied we are ordered to treat the scholars like this (Undlasi, 1977). Caliph Haroon Rashood sent his son to Imam Asmai for studies. Once he visited him and saw his son pouring the water on his feet during ablution. Haroon said I had sent my son for training; he replied he is doing same. Haroon said what should be if you order him to pour water with one hand and by another hand, he washes the feet (Naqshbandi, 2009).

\section{Conclusions}

Based on the above findings, the study concluded that formation of healthy and personal relationship between teachers and students was considered an indispensable element for successful teaching-learning process in Islamic history of education. Secondly, the relationship was based on pure intention, 
respect, trust, care, mutual understanding, and cooperation. The teacher was not merely responsible for delivering knowledge but was equally responsible for intellectual, materialistic, and spiritual development of the students. Therefore teacher's relationship with the students was based on guidance, counseling, encouragement, care, appreciation, development of good morals and creating a friendly environment. Thus the student in response used to behave with their teachers regarding respect, trust, honor, humbleness, and obedience. The author therefore recommends that the head of institutions should take guidance from the Islamic history of education to establish strong positive relationship between teachers and students. The research, therefore, endorses to establish strong and positive relationship among students and teachers by taking guidance from Islamic history of education. It would be helpful in improving quality of education, equipping learners with additional skills as well as making the educational process enjoyable.

\section{References}

Alkanderi, L. (2001). Exploring Education in Islam: Al-Ghazali model of the MasterPupil Relationship applied to educational relationships within the Islamic family.

Asif, K. (2004). Safeeran-e-Haram (Ambassadors of Haram). Karachi: Maktabatul Quraish.

Bhatti, M. A. (2010). Musalman Talib-e-Ilm (Muslim Student). Islamabad: Dawah Academy.

Dawd, A. ( 2009). Sunan abi Dawd. Ryaz: Darul Salam.

Fazl-e-Ilahi, D. (n.d.). Bachon Ka Ihtesaab (Children' Accountability). Lahore: Maktaba Quddusia.

Ghazali, A. H. (n.d). Ihya ul Uloom (Revival of Sciences). Lahore: Progressive Books. https://en.oxforddictionaries.com/definition/rela tionship

Ibn-e-Qattaan. (1997). Al Wahm-wal-Ehaam (Fantasy and Suspicion), Vol.5.AL Riyad: Dar Tayyaba.

Kanani, I. b. (2004). Tazkira-ul-Samey-walMutakallim-fi-adab-il-Alim-wal Mutaallim (Mentioning Listener and Speaker). Lahore: Bait ul Uloom.

Liberante, L. (2012). The importance of teacher-student relationships, as explored through the lens of the NSW Quality Teaching Model. Journal of Student Engagement: Education matters, 2-9.

Moes, M. F. (n.d.). Creating Islamic Culture in Muslim Schools. Capella University.

Murad, K. J. (1985). Ihya e Islam aur Muallim (Islamic Revival and Teacher). Lahore, Pakistan: 8-A Zaildar park, Ichra.

Mustafai, M. F. (2010). Bachon ki Taleem-oTarbiat (Training of Children). Vinea wala, Gujranwala: Maktaba-un-Noman.

Nadvi, H. (1995). Afkar Ibn-e-Khaldoon (Thouhgts of Ibn-e-Khaldun). Lahore: Idara Saqafat e Islamia.

Naqshbandi, M. R. (2009). Talib-e-ilm k shabo-roz (Day \& Night of Student). Bahadarabad, Karachi: Maktaba-ulSheikh.

Nizami, M. T. (2010). Aolad ki Tarbait kese Karen (How to train children). Rawalpindi: Maktaba Usmania.

Nofal, N. (2000). Al-Ghazali. Paris: UNESCO: International Bureau of Education.

Qasim, M. (2011). Ilm or Ulama ki Ahmait (Importance of Knowledge \& Scholars). Faisalabad: Maktaba Ahl e Sunnat. 
Shalbi, D. A. (1999).History of Muslim education. Lahore: Idara saqafat-eIslamiah.

Sheikh, D. M. (1984). Musalman Ustaz (Muslim Teacher). Lahore: Maktaba Tameer-e-Insaniyat.

Ulwan, A. N. (2000). Child Education in Islam. Cairo, Egypt: Dar ul Salam.

Undlasi, I.-e.-A.-u.-B. (1977). Jamey-bayan-ulIlm-wa-fadlih (Comprehensive Description of Knowledge and its Excellence). Lahore: Idara Islamiyat.
Urooj, D. (2013). Effects of positive teacherstudents relationship on students' learning. Interdisciplinary journal of contemporary research in business, 616-624.

Usmani, M. T. (n.d.). Aolad ki Islah o Tarbiat (Moral training of Children). Memon Islamic Publications.

Zulqarnain, M (2014). Teacher-Student Relationship in Contemporary Education System and Its Analysis within the Islamic Context. 